\title{
A Well-Known Malaysian Physicist's Idea on the Islamisation of Science towards Self Enhancement
}

\author{
Hazwani Che Ab Rahman, Nur Asyikin Binti Hamdan, Abdul Latif Samian, \\ Nazri Muslim \\ Institut Alam dan Tamadun Melayu, Universiti Kebangsaan Malaysia, 43600 Bangi, Selangor, Malaysia \\ Pusat Citra Universiti, Universiti Kebangsaan Malaysia, 43600 Bangi, Selangor, Malaysia
}

\begin{abstract}
Science is a knowledge that has become a tool for technological formation and advancement to ensure the development of the communities and countries. Science is also one of the fundamentals of the establishment of national identity through education. Nevertheless, science which has been taught to the society these days is accepted based on liberal and secular belief formed by the Western. Science at the present time is developed and distributed based on the nature and personality of Western culture. Therefore, effort to change the Western science or specifically called as the Islamisation of Science', is a responsibility that must be held by intellectuals. Islamisation of science is an effort introduced by Syed Muhammad Naquib Al-Attas, Ismail AlFaruqi, Seyyed Hossein Nasr and many other intellectuals to restore the integration between science and Islam. This study highlighted an intellectual who has contributed greatly in the Islamisation of science as well as his thoughts and ideas in promoting the Islamisation of science. Mohd Yusof who has popularized the 'Tauhidik Science' book is among intellectuals who has voiced out his ideas through writing, oral presentation and various activities in which the objective is to islamise the science. Mohd Yusof's idea has been referred to as an evaluation of thought and effort to restore the identity of Muslims through education.
\end{abstract}

Keywords: Islam, Islamisation of science, Mohd Yusof, identity.

\section{INTRODUCTION}

Identity is a complex issue to discuss with everyone in a country, especially in Malaysia that consists of various races, religions and cultures. However, this issue will be more easily and accurately if it is discussed separately according to races and nations. According to Wan Mohamad (2010), identity refers to an outward identity of the true self or the original self of a person as well as the values that he holds. Individual identity refers to his national identity, while the values that he holds refer to religious teachings as well as cultural practices and heritage he follows.

Islam is a religion which emphasizes its followers to acquire useful knowledge to strengthen the identity of an ideal human being. True Malays who are not influenced by Western propaganda that is secular and materialistic will accept and practice Islamic teachings as a way of life. Besides that, holistic or comprehensive Islamic values are emphasized in their life. History had recorded that peninsular Malaysia or its original name, Tanah Melayu, has been led by Malays and these people, too, are responsible for the development of Malay civilization. Thus, the identity discussed is referring to Malay identity as the national identity. National identity is not just suddenly appeared at the time of independence. Even before the advent of colonial, identity has become a symbol of national pride (Zainul Rijal, 2010).

Malays are the only people who get the privileges more than people of other races. According to the Federal Constitution, Malay refers to a Muslim who speaks the Malay language and follows Malay customs and practices (Federal Constitution, Article 160 [2]). Malay definition in the Federal Constitution states that anyone who is Malay should be a Muslim and practice Malay customs. However, if someone is from Malay background but he is non-Muslim and practicing the culture and customs of the non-Malay community, it is not feasible for him to be called as Malay because Islam is the basis of Malay identity.

The enhancement of national identity is formed and strengthened through Malay heritage and education that meet Islamic religious requirements to ensure the benefit of life, not only in this world but also in the hereafter. There are four main pillars in the creation of Malay identity (Nik Rosila, 2009), which are piety, morality, knowledge and relationship among them. However, this paper is focusing more on the knowledge about the science. To generate the strength of a nation and country, the strength of religion should be constructed and developed at all levels of education (Tajul Ariffin\&Nor 'Aini, 2002). However, if we look at the situation today, the spread of knowledge especially science to the community is mostly not following the Islamic requirements. Science at present has been through secularism process without the Creator and thus, will create a greed person for the worldly profit alone. 
The efforts to restore Malay identity and more significantly, Muslim identity is through education and delivering the science knowledge that follows the Islamic requirements. Returning or cleansing knowledge from secular elements is necessary so that the knowledge of science that is being delivered does not damage the national identity and distance its relationship with Islam. The process necessary to restore the knowledge back to its Creator is called as the Islamisation of science. Thus, the Islamisation of knowledge or science is the answer to Malay identity issue through education.

\section{THE CONCEPT OF ISLAMISATION OF SCIENCE}

Islamisation of knowledge in Arabic is known as "Islamiyyat al-Ma'rifat". According to Syed Muhammad Naquib Al-Attas (1978), the islamisation of knowledge is the process of separating the knowledge from secular ideology, meaning and expression. After the separation, the knowledge will be independent from Western elements and main concepts, and then combined with the elements and concepts of Islam. Seyyed Hossein Nasr (1994) defines the Islamisation of knowledge as a process of integrating various disciplines of modern knowledge into Islamic worldview or Tasawwur Islam. Moreover, according to Ismail Al-Faruqi, the islamisation of knowledge is the islamisation of new knowledge into the scope of Islamic tradition by removing, altering, reinterpreting and adapting its components as determinants of the Islamic worldview and values (Rosnani \& Imron, 2000).

Science and Islam are two things that share the same purpose in seeking the truth for any issues and facts. Not all issues related to real phenomena in this world can be answered by science. However, Islam is able to provide basic answer to questions that cannot be answered by science, as every question arises is attributed to the Creator. According to Baharuddin (2008), previously, science which was created based on Islamic thought is never impractical. In fact, it is balanced. However, it failed to be created in modern science due to Western thought and lifestyle for more than 300 years. Recently, science and technology are perceived based on limited thinking and they are only useful for particular purposes. This phenomenon must be reinstated as it was formed in the history of Islamic thought, and effort to return it based on the pillars of Islam, Faith and Ihsan is called as the 'Islamisation of Science'.

Syed Muhammad Naquib al-Attas, Ismail al-Faruqi and Seyyed Hossein Nasr are three prominent figures who have played an important role in realizing the Islamisation of science. The Islamisation of science has become an important and meaningful agenda for Muslim scholars as they began to assess science in accordance with the Islamic teachings until some components of science had to be removed, modified, and reconstructed based on the Islamic teachings. They subsequently published scientific knowledge which really follows the Islamic teachings and are able to compete the scientific knowledge shaping by Western scholars (Shaharir, 2009). Thus, the main task of the intellectuals or the exponents of the idea of Islamisation of science is to create a research study based on the Islamic teachings, stop the existing science and repair the Islamic way so that it is consistent with science that has Western elements and attributes.

Science is universal and in fact, there is no barrier which can break the relationship between science and Islam. Islam and science are inseparable because both are from the same Creator. Therefore, science should be assessed and refined based on the values which are in line with local and Islamic preference. This is necessary for the sustainability of knowledge and human being in order to identify the real way to put something righteously (Shaharir, 2009). Even the concept of Islamisation that is attached to science which is separated from the Creator must meet the conditions of the conversion, which conform to the Islamic law, faith and Ihsan, as was first described by Prophet Muhammad S.A.W. in his second hadith in the book of 40 Hadith by Imam Nawawi.

The Islamisation of science is an effort that has been proposed by Syed Muhammad Naquib Al-Attas and subsequently followed by Ismail al-Faruqi who made it more organized. The idea of the Islamisation of science was presented and discussed in the first World Conference of Islamic Education held in Mecca in April 1977. Syed Muhammad Naquib al-Attas presented his main paper entitled 'Preliminary Thoughts on the Nature of Knowledge and Definition and Aims of Education'. To ensure his idea of Islamisation of knowledge is continued, a worldwide conference was made in 1980 in Islamabad, 1981 in Dhaka, 1982 in Jakarta, 1985 in Egypt, 1990 in Amman and 1996 in Cape Town.

\section{STATEMENT OF THE PROBLEM}

In addressing the problem of modern science and technology culture through the history of its philosophy and results, a framework of science philosophy should be revived. The purpose and effort taken do not mean to criticise science and technology but to make the reality of events and human beings bigger. It will be a cohesive and balanced philosophy and make the science and technology as a branch of knowledge rather than 'knowledge' entirely. In this case, we do not only look forward in searching the 'new' meaning, but also retrospectively to see human beings who had lived by discovering the meaning in interpreting the events. We should not be caught up in the dynamics of the timeline concept as if human beings are always moving towards 
perfection without making mistakes. Looking back means perceiving the tradition of belief that was built by Islamic scholars and philosophers in the past and exploring each of them carefully and comprehensively which lead to positive meaning from the context of their belief. Religious community have built their civilization earlier than modern community, and when they want to rebuild the philosophy of science with the definition and meaning of their own, they should look at relevant and close examples; which mean close in terms of meaning and not in terms of time and period (Baharuddin, 2008).

Modern science from Western has created the idea that 'scientific and objective knowledge is neutral, unaffected and does not support certain beliefs and ideologies'. Whereas, when they said that science is neutral, it is not as neutral as they believed. It is only neutral from Islamic values, and not to values such as secularism or liberalism. This is one of chaos caused by the destruction of the basic concepts of knowledge. The Western culture has removed the religious values of knowledge. Knowledge which was previously associated with the power of Allah is no longer happened. It appears to be standing alone and to comply with own law which is the natural law that occurs naturally (Budi Handrianto, 2010). This is a major problem that must be addressed to ensure that the shortcomings and confusions existed for so long are rectified. Referring to Abdul Latif (1999) who stated that, 'not all religious matters are mathematical problems even in Islamic mathematical knowledge, all mathematical problems are religious matters', (similarly, the matters of other branch of knowledge are also religious issues that need to be solved), then the problem should be solved wisely so that it is within religious framework based on the pillars of Islam, Faith and Ihsan as described by the Prophet Muhammad in his hadith. Thus, the Islamisation of knowledge' is the answer to solve this problem.

Agendas and strategies in the Islamisation of science are still not perfect to solve the problem of separation between science and religion because science has long been secularized by the West. Separation between the theology and philosophy of nature that happened in Western Europe in 1800 has brought intense impact to the philosophy of each branch of knowledge. Before the separation, sciences such as chemistry, life sciences and physics lie entirely in the religious arena but after the separation, they ultimately do not have any relationship with religious activities (Abdul Latif, 1999). Here comes the importance of different opinions from various Muslim scholars and thinkers of specific areas in relation to the idea of Islamisation of science. These opinions need to be collected and integrated to guide the whole process of Islamisation of knowledge as they are strong and based on the Quran and the Hadith. For the purpose of this integration, one of the prominent figures who has involved in the Islamisation of science has been selected to study his opinions and integration strategies of the Islamisation of knowledge.

In general, the idea of Islamisation of science is too abstract as it is not expressed and carried out in accordance with empirical science where many Muslim intellectuals and thinkers are still unclear about how this idea can be implemented empirically in science research (Mahadi, 2014), despite the fact that they are supporting the idea of Islamisation of knowledge. Their ideas are trapped and limited by daily habits that are already moulded by Western through theories, methods, research processes, references and reading materials as well as tools and standards that have almost been entirely produced, specified and outlined by modern Western science institution. Habit was the cause of the limitations and it prevents reasonable idea to implement the Islamisation of knowledge. This has led to the need of references of Muslim philosophers and the Islamic philosophy of science which was trying to get out of the Western ideologies that disregard the existence of God. This figure who first realized, cared, reliable and active in advocating the agenda of Islamisation of knowledge to be more precise, detail and accepted by Islam, science and human themselves. Therefore, Mohd Yusof is one of the Malay prominent philosophers in science who has been chosen for this research.

\section{RESEARCH METHODOLOGY}

This study is a qualitative research and it is a descriptive analysis on Mohd Yusof's idea in realizing the idea of Islamisation of knowledge through Tauhidik science approach that has been proposed by him. To carry out this study, researchers have acquired different sources for qualitative data and information through written materials such as books, journals, monographs, articles and paper works from seminars, conferences, scientific discussions, lecture notes and research findings related to the topic. The documentation consists of primary source and secondary source. The primary source is the data obtained from the writing and research conducted by Mohd Yusof himself, while the secondary source is the publications related to Islamisation of knowledge, history and philosophy of science.Qualitative data were also obtained through interview with Mohd Yusof. All data collected are compiled and analyzed using the analysis of Mohd Yusof's response related to the Islamisation of knowledge. Meanwhile, the approaches used in the analysis of the study are terminology, methodology of Islamisation of knowledge and epistemology. 


\section{THE BACKGROUND OF MOHD YUSOF OTHMAN}

Mohd Yusof is a prominent figure in higher level of education in Malaysia. He was born on August 12, 1952, in Paya Keladi, Seberang Perai, Penang. He received his formal education from Sekolah Kebangsaan Paya Keladi. He continued his education in Sekolah Menengah Kebangsaan Kepala Batas and furthered his study in Sekolah Menengah Alam Shah in 1968. In 1972, he managed to further his study inThe National University of Malaysia (UKM) and had chosen physics course.

Mohd Yusof started his career in 1976 after graduating as a Bachelor of Science (Physics) from UKM and he was assigned as a lecturer in April 1976 at the UKM Matriculation in Sabah for a few months. In September 1976, he was offered to study abroad at Bedford College, University of London in the field of Solid State Physics for a year. Later, in December 1977, he resumed his career as the lecturer at UKM which was still located atJalan Pantai for three years. After that, he stopped his career for a while as he continued his studies in the degree of Doctor of Philosophy (Ph.D) in 1984 in the field of Solar Energy at the University of Aston, United Kingdom.

Mohd Yusof is a Physics Professor at The National University of Malaysia (UKM). Previously, he was the Chairman at the Department of Physics from 1990 to 1994. In 1994 to 2002, he was the Deputy Dean of the Faculty of Science and Technology, while in 2002 until 2007, he hold the position of the Director of Research Management \& Innovation, UKM. He is currently (2016) served as the First Director of Islam Hadhari Institute since July 2007 at that university. He has written more than 350 journal articles, post-trials, and seminars in Renewable Energy, physics, as well as education and philosophy of science. He has written over 28 books in physics and general reading and has registered for 11 patents (Mohd Yusof, 2013).

\section{MOHD YUSOF OTHMAN'S CONTRIBUTION IN THE ISLAMISATION OF SCIENCE TOWARDS SELF ENHANCEMENT}

Mohd Yusof is one of the language activists. He is outspoken in upholding and strengthening the use of the Malay language especially in the national education system. In most of his books such as the "Introduction of Tauhidik Science" (Mohd Yusof, 2014) and the "Science, Society and Religion" (Mohd Yusof, 2009), there is specific chapters which discuss the importance of the Malay language. In 2006, he had presented a research paper entitled "Keunggulan Bahasa Melayu: Menyongsong Tatanan Baru Dunia" in Language and Literature Seminar in conjunction with the Brunei-Indonesia-Malaysia Language Event (MABBIM). His views from his writing and research paper have highlighted the importance of the Malay language particularly in education. His efforts in preserving the use of the Malay language through writing, seminars and lectures have become a significant effort to ensure the importance of the Malay language is guaranteed in the eyes of his own people.

Education is the product of the language and it will always depend on the language to implement it. This is because education involves presentation, interpretation, analysis, synthesis, understanding as well as practice of the concepts and ideas, thus reflecting the fact that all of them are in need of language (Wan Mohd Nor, 2005). According to Mohd Yusof (2014), when the Malay language is no longer a language that conveys scientific and technological knowledge, the values of religion and Malay culture which cannot be separated from Islam will be vanished. As a scientist, he is very confident that science and technology should be taught in national language. The use of English in science and technology does not only lead to weak and vague understanding to all students about science as well as reduce the role of the Malay language but also produce a generation who is too obsess with science from the West which does not provide a place to discuss the role of God and religion.

He is very proud to be fated by Allah to build his career at the UKM which is the only university in the world that aims to uphold the Malay language in all fields of education, especially in science and technology. His contribution in preserving the Malay language as a basis of national identity has been certified by the Ministry of Education in Malaysia which has awarded him as a Malay Academician in 2013. In fact, the Dewan Bahasa \& Pustaka is confident to make him a Publication Committee in 2012 until 2014.

The role of the Malay language has been faded by colonials (the Dutch in Indonesia and the West in Malaysia) by limiting the use of the Malay language as a global language into local language or vernacular language which only serves as a daily lingua franca and is used among the Malay community (Awang Sariyan, 2009). The importance of the Malay language was first noticed by Syed Muhammad Naquib al-Attas (1972) when he stated his concern towards the importance and functions of the Malay language which has been forgotten. Syed Muhammad Naquib al-Attas had introduced the idea of Islamisation of science since 1970 through language education programme, literature and culture at the UKM. According to him, the use and the assessment of the Malay language and literature were slightly done. The study of the Malay language and literature should include the study of religion, Malay philosophy, history and art as well as others.

Mohd Yusof is a scientist who has been involved in Renewable Energy research more than 30 years ago. His main contributions are in the study of solar radiation, solar thermal and photovoltaic system. His main 
research is in the design of solar thermal collector for water and hot air, system of solar water pumping, photovoltaic systems connected to the grid and the most recent is photovoltaic-thermal collector system (Mohd Yusof, 2012). In his efforts to realise the Islamisation of science that led to the establishment of the national identity of Malay Muslim, he, as a scientist and Malay Muslim thinker has introduced the Tauhidik Science as an approach to islamise the science.

Mohd Yusof (2014) stated that people need two consistent knowledge; the knowledge related to understanding the nature (science) and the knowledge related to the development of culture, identity and all values (human sciences) to have prosperous life. Science is the knowledge that allows people to understand their 'tabii' at a particular time. Science allows us to understand the nature. However, nature cannot be understood through science and technology only. Science is knowledge in relation to religion but it is unable to explain the religious knowledge through scientific methods. In order to clarify the meaning of science, he stated that it is important to understand the term 'tabii' first. Some said that tabii means the same as nature. However, these two words have different meanings. Nature means the phenomena happened naturally without being controlled by the power of God while tabii or habit is a trait, characteristic, or a natural phenomenon that obeys the laws of the Creator. He believed that scientific approaches to understand the natural phenomenon which is separated from the religion and society, and secular can be accepted and are not offensive to Muslims. However, the problem is when we, as Muslims are making it secular or separating the worldly affairs and the religious views as a system of life and a measure of all the work done. Religion should be the controller of all human action, while science is just a tool, a vehicle and a platform to understand the natural phenomenon and how to use it.

According to Mohd Yusof, the Islamisation of knowledge does not conclude the science of Islam proposed by Ismail al-Faruqi, Mohd Naquib Al-Attas, and Sayyed Hossein Nasr, but he has developed the Tauhidik science as an answer and approach to the process of Islamisation of science. Tauhidik science is a science based on the concept of the Oneness of Allah (tawhid). The Tauhidik science practice is based on the concept of Allah as The Creator, then all scientific activities to be carried out by human are subject to Sharia (Khalijah \& Mohd Yusof, 2009). Islamic science and Tauhidik science do not have significant differences, but they play a very important role in strengthening the idea of Islamisation of knowledge. Islamic science was introduced through a philosophical approach and epistemological argument, which is the study of the theory of science itself and those who are expert and discussing about that are philosophers (Mohd Yusof, 2014).

Tauhidik Science introduced by Mohd Yusof is the same approach used for the Islamisation of knowledge and the Islamisation of science as the concept of Tawhid in Tauhidik science is according to the teachings of Islam. According to Mohd Yusof (2014), Tauhidik science is the scientific knowledge that is not only able to explain natural phenomena around us, but it is a science that can explain to us the meaning of the natural phenomena that has been studied. Thus, Tauhidik science will explain the meaning of the natural phenomena and its relationship with The Creator, as well as the meaning and feeling of a person who has been educated by Tauhidik science. As a result, Tauhidik science will produce ethical and responsible scientists to the Creator. The concept used by Mohd Yusof (2014) in the Islamisation of science is very clear through Tauhidik science introduced by him. The main concept which is the basis for producing and understanding the Tauhidik science is the concept of tawhid which refers to the concept of God. The concept of God in Tauhidik science discusses about the Oneness of Allah the Almighty in arranging the nature. However, this concept is not the only concept used to understand the Tauhidik science, but the Tauhidik science must involve the concept of religion, God, caliphate, human being, knowledge, nature, wisdom, justice and truth.

Tauhidik science is based on a research related to the integration between science and religion which was conducted by researchers at the Faculty of Science and Technology, UKM, led by Khalijah Mohd Salleh. On the other hand, Mohd Yusof is one of the researchers who explained to the public about the concept of this science. Mohd Yusof has been trying hard to make the Tauhidik Science course as a compulsory course need to be taken by all students from the Faculty of Science and Technology, UKM. This course introduces the integration between science and religion, more divine-oriented and human-oriented, and nature, intellectuals and the Quran as the source of knowledge. This course serves as a source to the science students who are mostly Malay Muslim students. Hence, it is a required course offered to them which is related to Islamic point of view according to scientific context (Khalijah \& Mohd Yusof, 2009). As a reference to this Tauhidik Science course, Mohd Yusof wrote a special book entitled 'The Introduction of Tauhidik Science' (Mohd Tusof, 2014) based on his lectures at the UKM.

Science framework developed within the Western framework only involves the relationship between human beings and nature. They only use intellectual intelligence and common sense to understand the systematic nature through the practice of the scientific methods. The nature is benefited by them through the technology they developed merely for the benefit of certain people. However, within the framework of Tauhidik science, it is based on the relationship between the Creator, the man and the nature which are clearly divided into three main relationships; the relationship between God and nature, the relationship between God and man and the relationship between man and nature. Tauhidik science is a science that contradicts the principles of Western 
science as it emphasises the role of God as the Creator of all things with the concept of the Oneness of Allah (Tawhid) who has the absolute power to control the nature. The conceptual framework that build the Tauhidik science comprises five main entities which are the divine entity of Allah, the human entity, the natural entity, the Quran entity and the Sunnah entity. The God is the Creator, human beings and nature acts as the creations while the Quran and the Sunnah are the creations which provide guidelines, limitations of the study as well as guidance towards a systematic life in this world and the hereafter.

His active involvements in the field of religion and science has led him to continue strengthening the idea of Islamisation of knowledge and trying to explain to the public about the concept of religion and science as well as the relationship between these two. Through his contribution, he has been chosen as the first Director of the Institute of Islam Hadhari, UKM since 2007 until now (2016). In fact, he has been trusted to hold positions like the Panel of the Malaysian Consultative Council of Islamic Organization, Prime Minister's Department in June 2014, a Fellow at the Academy of Sciences Malaysia since 2014, Honorary Fellow at the Islamic University Malaysia (2014-15), Honorary Fellow at the Institut Kefahaman Islam Malaysia IKIM (2005-07), Honorary Fellow at Sultan Zainal Abidin University (UniSZA) (2014). He is also a member of the National Council of Islamic Affairs of Malaysia since 2006, Secretary of the Da'wahPanel for Malaysian Consultative Council of Islamic Organization (2008-2011), member of the National Da'wah Council (2014-16), and member of the Advisory Board, Wasatiyyah Institute Malaysia (2013-15) (Mohd Yusof, 2013).

His contribution in the Islamisation of science has been translated orally and through writing. Among his writing are, 'Isu dalam Ilmu dan Pemikiran' (1998), 'Menjejak Kualiti Menjana Kecemerlangan' (2002), 'Sains dalam Maqasid Al-Quran' (2013), proceedings of the Science Tauhidik Teaching Workshop titled 'Mengapa Dunia Memerlukan Sains Tauhidik?'(2010), 'Etika dalam Sains: Tauhidik Berbanding Sekular' (2010), 'Pandangan Masyarakat Terhadap Sains Kontemporari' (2010), seminar paper titled 'Al-Quran and Science (Nuclear) (2010) and many more. His contribution, position and writing have shown his role in upholding the idea of Islamisation of science. As an educator who is sensitive to the needs of his students for science that recognizes the role of their Creator, he tried to carry out his responsibility to establish the identity of a religious nation. His efforts in education have attracted the attention of many parties where he was awarded the Nobel Prize for Maal Hijrah (1426H-2006) from the Government of Malaysia, and the Tokoh Maal Hijrah Award from the Government of Penang (1429H-2008).

\section{CONCLUSION}

Malays should strengthen their identity by practicing the teachings of Islam in all their daily affairs, especially in education that provides benefits for the worldly life and the hereafter. They have to be aware, try to avoid from being influenced by the Western and find a system that really suits the human spirit who believes in God. Our understanding of the physical nature depends on the theory of that phenomenon. Therefore, if there is an error in the theory, there will be misunderstanding towards the phenomenon (Abdul Latif, 2012). The Islamisation of science is the responsibility of the entire Muslim scientists and scholars who are not influenced by science from the West or secularization and diminish the dignity of the nation. The power of idea to empower and islamise the science is a real effort to defend the position of Islam in society that upholds the dignity of knowledge from diversion of certain parties who have their own agenda and interest, and indirectly able to resist secularization and safeguard Islam in society at present and in the future.

\section{REFERENCES}

[1] Abdul Latif Samian. 1999. Falsafah Matematik. Kuala Lumpur: Dewan Bahasa dan Pustaka.

[2] Abdul Latif Samian. 2012. Memetakan Metamatematik. Bangi: The National University of Malaysia.

[3] Awang Sariyan. 2009. Peranan Bahasa Dalam Pembinaan Insan Dan Pembangunan Masyarakat Hadhari. Jurnal Hadhari: 1-29

[4] Budi Handrianto. 2010. Islamisasi Sains. Jakarta: Pustaka Al-Kautsar.

[5] Nik Rosila Nik Yaacub. 2009. Pembinaan Identiti Diri Bangsa Melayu: Dari Perspektif Pendidikan Psikososial. Pulau Pinang: Universiti SainsMalaysia.

[6] Khalijah Mohd Salleh \& Mohd Yusof Othman. 2009. Sains Tauhidik Sebagai Satu Kursus STPD. Kertas kerja dalam Seminar Pendidikan Sains Teknologi Maklumat (SteM '09). The National University of Malaysia.

[7] Mohd. Yusof Othman. 1998. Isu dalam Ilmu dan Pemikiran. Kajang, Aras Mega Sdn. Bhd.

[8] Mohd. Yusof Othman. 2002. Menjejak Kualiti Menjana Kecemerlangan. Kuala Lumpur: Dewan Bahasa dan Pustaka.

[9] Mohd. Yusof Othman. 2009. Sains, Masyarakat dan Agama. Kuala Lumpur: Utusan Publications \& Distributors Sdn Bhd. 
[10] Mohd. Yusof Othman. 2010. “Mengapa Dunia Memerlukan Sains Tauhidik?”. Prosiding Bengkel Pengajaran Sains Tauhidik, Kumpulan Penyelidikaan Membina Graduan Penyelidikan dalam Sains dan Teknologi, Fakulti Sains dan Teknologi, The National University of Malaysia, 2010.

[11] Mohd. Yusof Othman. 2010. "Etika dalam Sains: Tauhidik Berbanding Sekular". Prosiding Bengkel Pengajaran Sains Tauhidik, Kumpulan Penyelidikaan Membina Graduan Penyelidikan dalam Sains dan Teknologi, Fakulti Sains dan Teknologi, The National University of Malaysia, 2010.

[12] Mohd. Yusof Othman. 2010. "Pandangan masyarakat Terhadap Sains Kontemporari”. Prosiding Bengkel Pengajaran Sains Tauhidik, Kumpulan Penyelidikaan Membina Graduan Penyelidikan dalam Sains dan Teknologi, Fakulti Sains dan Teknologi, The National University of Malaysia, 2010.

[13] Mohd. Yusof Othman. 2010. “Al-Quran dan Sains (Nuklear)”. Seminar Al-Quran Peringkat Pulau Pinang 1431H/2010M, anjuran Kerajaan Negeri Pulau Pinang di Dewan Melenium, Kepala Batas, 18 Julai 2010.

[14] Mohd. Yusof Othman. 2012. Gagasan 1Malaysia: Kreativiti \& Inovasi Dalam Pembinaan Peradaban. Purrajaya: Akademi Kenegaraan BTN, Jabatan Perdana Menteri.

[15] Mohd. Yusof Othman. 2013. Sains dalam Maqasid al-Qur'an. Bangi: Institut Islam Hadhari UKM.

[16] Mohd. Yusof Othman. 2014. Pengenalan Sains Tauhidik. Kuala Lumpur: Dewan Bahasa dan Pustaka.

[17] Rosnani Hashim \& Imron Rassidy. 2000. Islamisation of Knowledge: A Comparative Analysis of Conceptions of Al Attas and Al Faruqi. Intellectual Discourse Journal. 8(1) .19-44.

[18] Sayyed Hossein Nasr. 1994. A Young Muslim Guide To The Modern World. Kuala Lumpur: Mekar Publisher.

[19] Syed Muhammad Naquib Al-Attas. 1972. Islam dalam Sejarah dalam Kebudayaan Melayu. Bangi:UKM.

[20] Syed Muhammad Naquib al Attas .1978.Islam and Secularism. Kuala Lumpur: Muslim Youth Movement of Malaysia.

[21] Tajul Ariffin Noordin \& Nor 'Aini Dan. 2002. Pendidikan dan Pembangunan Manusia: Pendekatan bersepadu. Selangor: Al-Syabab Media.

[22] Wan Mohamad Sheikh Abdul Aziz. 2010. Strategi, kaedah dan pelaksanaan dakwah dalam membina jati diri kebangsaan. Dlm. Mohd. Yusof Othman (pnyt.). Jati Diri Kebangsaan Manhaj Islam Hadhari, hlm. 85-96. Bangi: The National University of Malaysia.

[23] Wan Mohd Nor Wan Daud. 2005. Falsafah dan Amalan Pendidikan Islam Syed M. Naquib Al-Attas: Satu Huraian Konsep Asli Islamisasi. Kuala Lumpur: Penerbitan Universiti Malaya.

[24] Zainul Rijal Abu Bakar. 2010. Undang-undang Islam di Malaysia: Ke arah pembentukan jati diri kebangsaan. Dlm. Mohd. Yusof Othman (pnyt.). Jati Diri Kebangsaan Manhaj Islam Hadhari, hlm. 6784. Bangi: Institut Islam Hadhari, UKM. 